\title{
Milk disrupts p53 and DNMT1, the guardians of the genome: implications for acne vulgaris and prostate cancer
}

\author{
Bodo C. Melnik
}

\begin{abstract}
There is accumulating evidence that milk shapes the postnatal metabolic environment of the newborn infant. Based on translational research, this perspective article provides a novel mechanistic link between milk intake and milk miRNA-regulated gene expression of the transcription factor p53 and DNA methyltransferase 1 (DNMT1), two guardians of the human genome, that control transcriptional activity, cell survival, and apoptosis. Major miRNAs of milk, especially miRNA-125b, directly target TP53 and complex p53-dependent gene regulatory networks. TP53 regulates the expression of key genes involved in cell homeostasis such as FOXO1, PTEN, SESN1, SESN2, AR, IGF1R, BAK1, BIRC5, and TNFSF10. Nuclear interaction of p53 with DNMT1 controls gene silencing. The most abundant miRNA of milk and milk fat, miRNA-148a, directly targets DNMT1. Reduced DNMT1 expression further attenuates the activity of histone deacetylase 1 (HDAC1) involved in the regulation of chromatin structure and access to transcription. The presented milk-mediated miRNA-p53-DNMT1 pathway exemplified at the promoter regulation of survivin (BIRC5) provides a novel explanation for the epidemiological association between milk consumption and acne vulgaris and prostate cancer. Notably, p53- and DNMT1-targeting miRNAs of bovine and human milk survive pasteurization and share identical seed sequences, which theoretically allows the interaction of bovine miRNAs with the human genome. Persistent intake of milk-derived miRNAs that attenuate p53- and DNMT1 signaling of the human milk consumer may thus present an overlooked risk factor promoting acne vulgaris, prostate cancer, and other p53/DNMT1-related Western diseases. Therefore, bioactive miRNAs of commercial milk should be eliminated from the human food chain.
\end{abstract}

Keywords: Acne vulgaris, Cancer, Chromatin, DNA methyltransferase 1, Exosome, Gene expression, Milk, miRNAs, p53, Prostate cancer

\section{Introduction}

Milk is the postnatal nutrient and programming system of mammals, which promotes adequate growth and organ development. Growth and tissue maturation require enhanced gene expression, which is controlled by a host of genetic and epigenetic factors recently linked to complex interacting signal transduction pathways mediated by milk's mTORC1-activating essential amino acids as well as milk exosome-derived miRNA signaling [1-8]. The transcription factor $\mathrm{p} 53$, designated as the guardian of the human genome [9], controls approximately $1 / 10$ th of human gene promoters that contain p53-binding sites and are thus p53 target genes [10,11]. Dependent on the particular gene, p53 either promotes

Correspondence: melnik@t-online.de

Department of Dermatology, Environmental Medicine and Health Theory,

University of Osnabrück, Am Finkenhügel 7a, D-49076 Osnabrück, Germany or inhibits gene expression [9-11]. High-confidence p53 target genes are involved in multiple cellular responses, including cell cycle arrest and apoptosis [11]. Recent evidence underlines that miRNAs control p53 expression [12]. Intriguingly, several miRNAs detected in human and bovine milk are known suppressors of TP53, the gene expressing $\mathrm{p} 53$. The very high sequence homology of human and bovine milk miRNAs [13], especially in their seed region governing their function, suggests that uptake of milk-derived miRNAs may compromise the delicate balance in the level of key gene regulatory miRNAs deregulating the consumer's gene expression, which promotes pathophysiological processes such as acne vulgaris (Av) and prostate cancer (PCa). Thus, the question arose as to whether milk exosome-derived miRNAs affect the expression of p53 and p53-dependent gene regulation of the milk recipient such as the breastfed newborn infant and the regular consumer of cow's milk. 
From a mechanistic point of view, an attenuation of p53-mediated cell cycle inhibition and apoptosis during the lactation period would facilitate cell cycle progression, growth and anabolism of the newborn infant. To achieve this goal, milk should interact with the p53related gene regulatory network of the milk recipient. It is the intention of this perspective to provide translational evidence that milk miRNAs may be able to disrupt the homeostasis of p53 and DNMT1, the guardians of the human genome $[9,14]$. This will be exemplified by a closer look to the two common Western diseases, acne vulgaris (Av) and prostate cancer (PCa), which both are closely related to increased consumption of commercial cow's milk.

Milk exosome-derived miRNAs resist intestinal degradation Milk is the human body fluid that contains the highest amounts of RNAs and miRNAs [15]. These RNAs and miRNAs are predominantly secreted by mammary epithelial cells (MECs) and are transported via extracellular vesicles (exosomes) to fulfill their regulatory tasks in the complex setting of mammalian reproduction $[2-7,16]$. There is increasing evidence that the specific encapsulation of milk miRNAs in exosomes (30-100 nm in diameter) and exosome-like vesicles (> $100 \mathrm{~nm}$ ) confers protection against miRNA degradation and creates a long-distance signaling pathway for intestinal and vascular endothelial transport by endocytosis, a potential requirement for miRNA delivery to peripheral tissues [17-24]. It has recently been demonstrated that human milk exosomes and their miRNAs survive digestion in vitro and are taken up by human intestinal cells [25]. Moreover, trans-epithelial transport of bovine milk exosomal miRNAs across intestinal Caco-2 cell monolayers indicated their potential to cross the intestinal barrier. Cow milk exosomes protect their miRNAs against harsh digestive processes and enable their crossing of the intestinal barrier to reach the blood circulation for distant cellular effects [26]. Notably, there was no significant difference in the levels of miRNA-148a, miRNA-21 and miRNA-25 between in vitro digested exosomes and their respective undigested controls [26]. Consumption of commercial milk resulted in a dose-dependent increase of miRNA-29b in peripheral blood mononuclear cells of healthy adult human volunteers associated with corresponding changes in gene expression [27]. Recently, Manca et al. [28, 29] provided compelling evidence that orally administered fluorophore (DiR)-labeled cow milk exosomes are bioavailable in mice. Notably, a fraction of exosomes escaped re-packaging in the intestinal mucosa. Labeled bovine milk exosomes accumulated in liver and spleen of mice. Exo-GLOW Red-labeled RNA derived from cow milk exosomes has been detected in the brain, kidneys, lungs and livers of mice after oral administration of these exosomes. The authors concluded that the cargos of dietary exosomes are delivered to peripheral tissues $[28,29]$. Thus, accumulating evidence underlines the bioavailability of orally administered bovine milk exosomes and their miRNA cargo, which survives gastrointestinal degradation, reaches the systemic circulation and modifies gene regulation in recipient cells of peripheral tissues. With the same intention, orally administered bovine milk-derived exosomes have been successfully used for systemic drug delivery to tumorbearing mice [30, 31].

\section{Milk exosomes deliver TP53-targeting miRNAs}

The expression of the p53 gene (TP53) is tightly regulated via transcriptional and post-translational modulations. Le et al. [32] demonstrated that miRNA-125b is a bona fide negative regulator of p53 in both zebrafish and humans. miRNA-125b-mediated down-regulation of p53 is strictly dependent on the binding of miRNA-125b to a miRNA response element in the 3 '-untranslated region (3' UTR) of TP53 mRNA (Table 1). It has recently been shown that miRNA-125b directly represses 20 novel targets in the vast p53 network including both apoptosis regulators like BAK1, IGFBP3, ITCH, PUMA, PRKRA, TP53INP1, TP53, ZAC1, and also cell-cycle regulators like cyclin C, CDC25C, CDKN2C, EDN1, PPP1CA, SEL1L, respectively [32]. Notably, miRNA-125b regulation of p53 is conserved at the network level in all vertebrates [33]. Milk contains abundant miRNA-125b, which has been demonstrated in human [34], bovine [18, 35], and porcine milk exosomes [36], respectively. Further TP53 targeting miRNAs are miRNA-30d, miRNA-25, and miRNA-504 [37]. miRNA-25 and miRNA-30d directly target the 3 '-UTR of TP53 to down-regulate p53 protein levels and to reduce the expression of genes that are transcriptionally activated by p53 [37]. Notably, miRNA-30d has been detected as a major signature miRNA of mature raw and commercial milk of dairy cows [38]. miRNA-30d has also been found in porcine milk exosomes and in human milk [35, 39, 40]. In addition, miRNA-25-3p has been observed in human and porcine milk exosomes [34, 39].

Remarkably, the mature and seed sequences of human and bovine miRNA-125b, miRNA-25, as well as miRNA-30d are identical (Table 1). This interspecies miRNA homology implies that milk miRNA-mediated p53 regulation may be a highly conserved archaic signaling pathway of mammals. These miRNAs target distinct 3'UTR regions of TP53.

\section{Milk-derived miRNAs and DNMT1 regulation}

Recent evidence underlines that DNA methylation is another "guardian of the genome" [41]. It is generally accepted that DNA hypomethylation destabilizes the genome [42]. 
Table 1 Illustration of human (hsa) and bovine (bta) mature and seed sequences of TP53- and DNMT1-targeting miRNAs (mirbase.org) with predicted base pairing regions marked in red (targetscan.org)

\begin{tabular}{|c|c|}
\hline $\begin{array}{l}\text { hsa-miR-125b-5p } \\
\text { bta-miR-125b-5p }\end{array}$ & $\begin{array}{l}\text { UCCCUGAGACCCUAACUUGUGA } \\
\text { UCCCUGAGACCCUAACUUGUGA }\end{array}$ \\
\hline $\begin{array}{l}\text { TP53 3’UTR (position 1022-1026) } \\
\text { hsa-miRNA-125-5p }\end{array}$ & $\begin{array}{l}5^{\prime} . . . \text { AAGACUUGUUUUAUGCUCAGGGU... } \\
\text { II I I I I I I } \\
\text { 3' AGUGUUCAAUCCCAGAGUCCCU }\end{array}$ \\
\hline $\begin{array}{l}\text { hsa-miR-30d-5p } \\
\text { bta-miR-30d-5p }\end{array}$ & $\begin{array}{l}\text { UGUAAACAUCCCCGACUGGAAG } \\
\text { UGUAAACAUCCCCGACUGGAAGCU }\end{array}$ \\
\hline $\begin{array}{l}\text { TP53 3'UTR (position 576-582) } \\
\text { hsa-miR-30d-5p }\end{array}$ & $\begin{array}{c}5^{\prime} \text {...UGCAGUUAAGGGUUAGUUUACAA... } \\
\text { I I I I I I } \\
\text { 3' GAAGGUCAGCCCCUA- -CAAAUGU }\end{array}$ \\
\hline $\begin{array}{l}\text { hsa-miR-25-3p } \\
\text { bta-miR-25-3p }\end{array}$ & $\begin{array}{l}\text { CAUUGCACUUGUCUCGGUCUGA } \\
\text { CAUUGCACUUGUCUCGGUCUGA }\end{array}$ \\
\hline $\begin{array}{l}\text { TP53 3'UTR (position 381-387) } \\
\text { hsa-miR-25-3p }\end{array}$ & $\begin{array}{c}5^{\prime} \text {...CUUUGAACCCUUGCUUGCAAUAG... } \\
\text { 3' I I I I I } \\
\text { 3' AGUCUGGCUCUGUUCACGUUAC }\end{array}$ \\
\hline $\begin{array}{l}\text { hsa-miR-148a-3p } \\
\text { bta-miR-148a-3p }\end{array}$ & $\begin{array}{l}\text { UCAGUGCACUACAGAACUUUGU } \\
\text { UCAGUGCACUACAGAACUUUGU }\end{array}$ \\
\hline $\begin{array}{l}\text { DNMT1 3'UTR (position 48-55) } \\
\text { hsa-miR-148a-3p }\end{array}$ & $\begin{array}{c}5^{\prime} \ldots \text { CAGGAAUCCCCAACAUGCACUGA... } \\
\text { I I I I I I I I } \\
3^{\prime} \text { UGUUUCAAGACAUCACGUGACU }\end{array}$ \\
\hline
\end{tabular}

DNA methylation is regulated by DNA methyltransferases [42]. The maintenance DNA methyltransferase (DNMT) 1 and the de novo methyltransferases DNMT3A and DNMT3B are all essential for mammalian development [42]. Thus, DNA methylation catalyzed by DNMTs plays an important role in maintaining genomic stability. Aberrant expression of DNMTs and disruption of DNA methylation patterns are closely associated with many forms of cancer [43-45]. The function of DNMT1 is tightly related to growth control [46]. DNMT1 is responsible for cytosine CpG methylation of DNA in mammals and has a role in gene silencing [42]. DNA methylation represses genes partly by recruitment of the methyl-CpG-binding protein $\mathrm{MeCP} 2$, which in turn recruits histone deacetylases [47]. DNMT1 is itself associated with histone deacetylase activity in vivo [47]. One of the known histone deacetylases, HDAC1, has the ability to bind directly to DNMT1 [47]. Thereby, DNMT1-mediated DNA methylation alters the chromatin state via HDAC activity [47]. The DNMT1 complex with HDAC1, Rb, and E2F1 represses transcription from E2F-responsive promoters [48] (Fig. 1).

Taken together, there is an intimate interaction between DNA methylation, histone deacetylase and sequence-specific DNA binding activity and the control of growth-regulatory pathways that are disrupted in nearly all cancer cells [48].
miRNA-148a is by far the most abundant miRNA detected in human milk, bovine colostrum and mature cow's milk, porcine colostrum and mature porcine milk $[25,34,38,39,49-51]$. Furthermore, miRNA$148 \mathrm{a}$ is highly expressed in human and bovine milk fat $[13,50,51]$ and has been detected in substantial amounts in bovine skim milk and human milk exosomes $[13,25,34]$. It is possible that milk fat globules (MFGs) of cow's milk release miRNA-148a carried in crescent exosomes of MFGs [52], especially after the process of homogenization [50]. Golan-Gerstl et al. [13] recently demonstrated that miRNA-148a-3p represents the top one miRNA of pasteurized skim milk (16.09\% of all miRNAs) and the top two miRNA of pasteurized milk fat $(7.16 \%)$, respectively. These data correspond to the findings of Do et al. [53] who confirmed that miRNA-148a belongs to the most abundantly expressed miRNA of bovine milk since it accounts for more than $10 \%$ of the read counts in each stage of dairy cow lactation. miRNA-148a, miRNA-148b, and miRNA-152 are three members of the miRNA-148/152 family, which shares substantial homology in their seed sequences [54].

Wang et al. [55] reported that the expression of miRNA-152 significantly increased during lactation in MECs of dairy cows producing high quality milk 


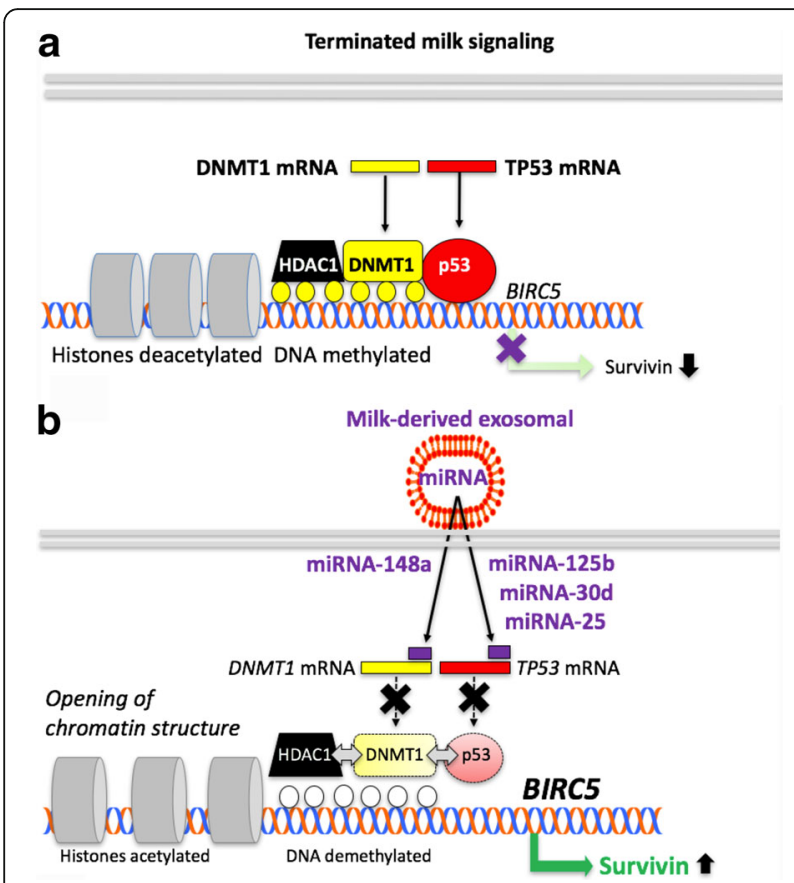

Fig. 1 Illustration of milk microRNA signaling regulating the expression of $B I R C 5$, the gene encoding the anti-apoptotic protein survivin. a. In the absence of milk-derived miRNAs, p53 suppresses survivin expression and attracts DNA methyltransferase 1 (DNMT1) to the BIRC5 promoter, which results in DNA methylation (yellow circles, gene silencing). DNMT1 binding to histone deacetylase 1 (HDAC1) results in histone deacetylation and subsequent chromatin compaction. b. During milk consumption, milk exosomal microRNAs enter the recipient cells and down-regulate the expression of both TP53 and DNMT1 mRNA leading to increased survivin expression. DNMT1 and HDAC1 are removed from the BIRC5 promoter resulting in DNA promoter demethylation and histone acetylation promoting gene expression and opening chromatin structure. Milk-derived p53- and DNMT1 targeting miRNAs thus operate as a switch regulating gene expression

compared to lower miRNA-152 levels in cows producing low quality milk. The forced expression of miRNA-152 in dairy cow MECs resulted in a marked reduction of DNMT1 at both the mRNA and protein levels [55]. Importantly, DNMT1 is a direct target of miRNA-148a [56]. The expression of DNMT1 is thus inversely related to the expression miRNA-148a and its family homolog miRNA-152 [57, 58]. Importantly, it has recently been shown that the expression of miRNA-148a of normal colon cells (CRL1831) and K562 leukemia cells increased after incubation with milk exosomes and the fat layer isolated from human milk [13]. The increased cellular expression of miRNA-148a was associated with a significant decrease in the expression of DNMT1 [13]. Lactogenic hormones such as prolactin induce cellular and extracellular miRNA-148a expression in bovine MECs [59]. Furthermore, miRNA-148a has been shown to induce milk triacylglycerol synthesis in goat MECs [60]. A recent study investigated genome-wide miRNA binding site variation between extinct wild aurochs and modern cattle and identified candidate miRNA-regulated domestication genes that enhance lactation performance including the MIR148A gene [61]. In fact, recent coexpression and network and pathway analyses identified bovine miRNA-148a as a major determinant enhancing milk yield [62].

miRNA-21 is another abundant miRNA of human and cow's milk [38], which indirectly inhibits DNMT1 expression by targeting Ras guanyl nucleotide-releasing protein-1 (RASGRP1) [56].

It is of critical importance to mention that the mature and seed sequences of human and bovine miRNA-148a are identical (Table 1). miRNA-148a homology of DNMT1-targeting miRNA-148a is regarded as an ancestral epigenetic regulator in various mammalian species [13]. DNMT1 suppression appears to be a generalized signaling mechanism of milk capable of enhancing mammalian gene expression, a meaningful regulatory step for the growing mammal during the period of lactation but a critical gene-destabilizing system during long-term exposure.

\section{Cooperation between p53, DNMT1 and HDAC}

Cumulative work suggests that p53 is not a stand-alone regulator but participates in a complex gene regulatory network. DNMT1, a key regulator of epigenetics, is an integral part of this network. DNMT1 has been shown to physically interact and bind to p53 and co-localizes in the nucleus [63]. Upon p53 induction, a reporter construct containing the promoter of the anti-apoptotic gene survivin (BIRC5), which contains a natural p53 binding site, was methylated in wild type HCT116 cells, but not in DNMT1 null or p53 null cells. Endogenous survivin gene repression involves cooperation between DNMT1 and p53 (Fig. 1), which is relieved by introduction of DNMT1- or p53-specific small inhibitory RNA (siRNA) [63]. It is thus conceivable that milk exosome-derived miRNAs in a comparable manner to siRNAs target p53 and DNMT1 and activate survivin expression and other antiapoptotic and growth promoting genes that are regulated in a p53-DNMT1-interacting fashion (Fig. 1). In contrast, activation of $\mathrm{p} 53$ down-regulates the anti-apoptotic protein survivin (Fig. 2) [64]. Survivin expression is absent in benign prostate specimens but high and associated with higher Gleason score in PCa [65]. DNMT1 is able to associate with histone deacetylase (HDAC) [10, 47], suggesting its involvement in transcriptional repression of chromatin by means of histone deacetylation [63]. DNMT1 activity via maintenance of the appropriate histone $\mathrm{H} 3$ modifications contributes to the preservation of the correct organization of large heterochromatic regions [64].

Milk miRNA-148a-mediated DNMT1 suppression may thus modify chromatin structure, unwinding chromatin to 


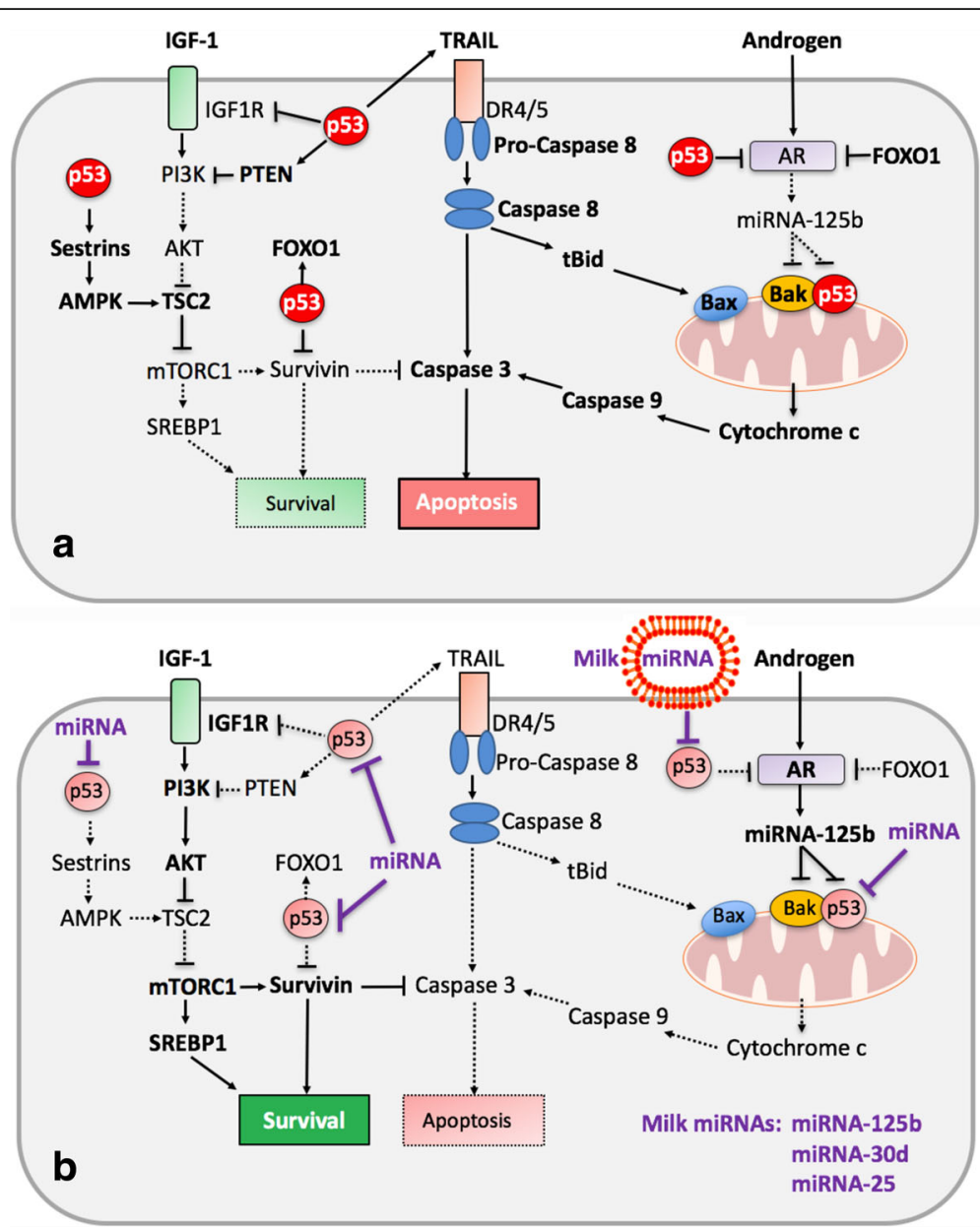

Fig. 2 Working model illustrating the potential impact of milk exosome-derived miRNAs on the expression of p53. a. In the absence of milk miRNAs, p53 is abundantly expressed. p53 inhibits mechanistic target of rapamycin complex 1 (mTORC1) signaling and directly reduces the expression of IGF-1 receptor (IGF1R). p53 enhances sestrin1/2-mediated activation of AMK kinase (AMPK), a critical negative regulator of mTORC1. Furthermore, p53 induces the expression of FOXO1, which is a negative regulator of androgen receptor (AR). The expression of tumor necrosis factor-related apoptosis-inducing ligand (TRAIL) is upregulated by p53, which activates the extrinsic and intrinsic (mitochondrial) pathway of apoptosis. AR expression is negatively regulated by p53 resulting in decreased AR-mediated expression of miRNA-125b, which targets the pro-apoptotic proteins Bak and p53 at the mitochondrial membrane. This stimulates the interaction of p53 with Bak promoting the intrinsic pathway of apoptosis. b. During milk intake, milk exosomal miRNAs interrupt p53 signaling. This promotes the PI3K-AKT-mTORC1 pathway enhancing the expression of survivin, which is a negative regulator of caspase 3. Furthermore, milk miRNAs via attenuation of p53 and FOXO1 expression enhance AR signaling with subsequent upregulation of miRNA-125b. Increased miRNA-125b expression via AR signaling and milk miRNA-125b uptake down-regulate Bak-p53-interaction suppressing the intrinsic pathway of apoptosis. Thus, milk orchestrates both pro-survival and anti-apoptotic signaling, a most favorable constellation for the growing infant but a disastrous promoter of diseases in patients associated with disrupted p53 homeostasis such as acne vulgaris and prostate cancer

allow access to the DNA sequence and subsequent transcription, important regulatory events for the growing mammal. As discussed for the BIRC5 promoter, p53 stabilizes the p53-DNMT1-HDAC1 complex (Fig. 1) [63]. DNMT1 potentially provides a key interaction via DNA methylation recruiting HDAC1 and acting as a bridge between nuclear p53 and chromatin, reinforcing a repressed chromatin state [66]. Milk miRNAs via targeting both p53 and DNMT1 would thus destabilize these key guardians of the human genome enhancing transcriptional activity for the restricted and privileged period of lactation (Fig. 1).
Milk miRNAs survive pasteurization and homogenization

Pasteurization of milk has been introduced into modern dairy technology to limit bacterial growth but not to eliminate milk's biological miRNA activity. There is recent evidence that substantial amounts of miRNAs of commercial cow's milk resist pasteurization and homogenization [13, 35, 67]. Milk miRNAs such as miRNA-21 and miRNA-29b were found stable under different household storage conditions indicating that milk miRNAs could be available to the human milk consumer [27, 35, 67]. Notably, the vast majority of cow milk-derived miRNA-148a has been shown to 
survive pasteurization, homogenization, and the attacks of digestive enzymes in comparison to untreated cow's milk [13, 26, 50]. In contrast, fermentation of cow's milk by addition of probiotic bacteria resulted in a substantial loss of milk's exosomal miRNAs exemplified by decreased recovery of miRNA-29b and miRNA-21 [23]. The authors discussed that bacterial attacks of exosome proteins deteriorates exosome membrane integrity, which may result in exosome miRNA degradation by miRNases secreted from microbes [23]. In comparison to pasteurized milk, fermented milk products such as yoghurt may thus exert diverse miRNA-dependent effects on human health. In fact, the EPIC-Interact Study $(n=340,234)$ demonstrated an inverse association of type 2 diabetes mellitus with a higher combined intake of fermented milk products compared to an increased association with unfermented milk [68]. With the widespread introduction of refrigeration technology in the early 1950's, milk's bioactive miRNAs unnoticeably entered the human food chain in a great and uncontrolled extent [6].

\section{The link between milk miRNA signaling, acne vulgaris and prostate cancer}

There is accumulating evidence that milk consumption during adolescence is linked to the occurrence or aggravation of Av [69-80]. Recent evidence points to increased pro-survival and attenuated apoptotic signaling in the pathogenesis of $\mathrm{Av}[81,82]$, which is therapeutically balanced by pro-apoptotic treatment with isotretinoin (13cis retinoic acid, the prodrug of all-trans retinoic acid (ATRA) [83, 84]. One most important ATRA-responsive gene is p53 [85]. Increased insulin/IGF-1 signaling in Av activates the kinase AKT, which inactivates nuclear FoxO1 via AKT-mediated phosphorylation [86-88]. It is important to note that nuclear FoxO1, the transcription factor of starvation [89], suppresses the androgen receptor (AR), a critical acne-inducing pathway also involved in PCa [90-94]. FoxO1 is also a negative regulator of the oncogenic transcription factor sterol regulatory element binding protein $1 \mathrm{c}$ (SREBP1c) $[95,96]$, which plays an important role in excessive sebaceous lipogenesis [97], a hallmark of Av [76]. Remarkably, p53 stimulates the expression of FOXO1 and phosphatase and tensin homolog (PTEN) [98]. PTEN antagonizes phosphoinositide 3-kinase (PI3K) and thus operates as a negative regulator of the IGF-1/PI3K/AKT signaling pathway that inactivates FoxO1 at the posttranslational level. Notably, weak p53 activity resulting from the single-nucleotide polymorphisms p53 G72C has been reported in the acne-associated SAPHO (synovitis, acne, pustulosis, hyperostosis, and osteitis) syndrome [99] (Fig. 2).

Therapeutic upregulation of the death receptor ligand tumor necrosis factor-related apoptosis-inducing ligand (TRAIL), which initiates apoptosis signaling has been identified as the primary mode of isotretinoin action in Av $[83,84]$. TRAIL activation is a recent major therapeutic strategy in the treatment of PCa [100-103]. It is important to realize that p53 directly induces the expression of TRAIL [104]. There are two p53 DNA-binding sites in the human TRAIL promoter region [104]. Thus, milk-miRNA-mediated down-regulation of p53 expression may attenuate apoptotic TRAIL signaling implicated to play a crucial role in the pathogenesis of Av and cancerogenesis of PCa (Fig. 2).

It is of critical concern that daily milk consumption in adolescence (vs. less than daily) was associated with a 3.2-fold risk of advanced PCa [105]. These findings point to a link between milk consumption, Av and PCa. In fact, an increased risk of PCa has been observed in men who suffered from more severe Av, which required oral tetracycline treatment [106]. Notably, increased IGF-1 and AR-mediated signaling with increased expression of survivin are related to both Av and PCa [88, 106-109]. Among patients diagnosed with localized $\mathrm{PCa}$, compared to men who consumed $<1$ servings/day of high-fat milk, those who drank $\geq 3$ servings/day had an increased hazard of PCa mortality [110]. Men with the highest versus lowest intake of whole milk were at an increased risk of progression among participants in the Health Professionals Follow-Up Study [111]. In accordance, whole milk intake but not total dairy protein intake has been associated with PCa-specific mortality among U.S. male physicians [112]. A recent comprehensive meta-analysis of 11 populationbased cohort studies involving 778,929 individuals confirmed the association between milk consumption and PCa [113]. Milk-induced Av and milk-driven PCa are both associated with increased mTORC1 signaling [88, 114-117]. Serum levels of IGF-1, a key stimulator of mTORC1 activity [118-125], increase during milk intake [124, 125]. Enhanced IGF-1 signaling has been related with the pathology of both Av [109, 126-129] and PCa [130], respectively. A recent meta-analysis substantiated a significant association between milk consumption and increased IGF-1 serum levels in patients with PCa [130]. The addition of milk to LNCaP cells in culture enhanced PCa cell proliferation by $30 \%$ [131]. It is important to emphasize that IGF-1/ mTORC1 signaling is negatively controlled by p53. p53 induces the expression of sestrin 1 and 2 [132, 133], which activate AMP kinase (AMPK), a pivotal negative regulator of mTORC1. Furthermore, p53 controls IGF-1-mediated activation of mTORC1 via p53-mediated reduction of IGF1 receptor (IGF1R) expression (Fig. 2) [134, 135].

Loss-of-function mutations of p53 are associated with a multitude of human cancers including PCa [136-139]. PCa specimen staining for p53 was inversely correlated with the age of patients with PCa [140]. Notably, Spyridonidis et al. [141] reported $\mathrm{PCa}$ in a patient with SAPHO syndrome. A persistent down-regulation of p53 
activity via p53 targeting milk-derived miRNAs may thus enhance PCa progression. Remarkably, a Swedish cohort study reported a relationship between daily milk intake and overall mortality [142]. In this study, milk consumption correlated with increased serum levels of interleukin-6 (IL-6) [142]. Intriguingly, p53 has been identified as a key suppressor of IL-6 and plays a pivotal role in suppressing inflammation and oxidative stress [143, 144]. Increased IL6 expression has been detected in PCa specimens and has been related to PCa carcinogenesis [145]. IL-6 is also a major pro-inflammatory mediator that is up-regulated in the skin of patients with Av (Table 2) [146, 147] .

The etiology of benign prostatic hyperplasia $(\mathrm{BPH})$ and prostatic neoplasia, which can progress to $\mathrm{PCa}$, is androgen-dependent, and reduction/obliteration of androgen action in the prostate has been the therapy of choice for $\mathrm{BPH}$ and $\mathrm{PCa}$ [148]. A recent study demonstrated that cases of PCa exhibited a higher staining intensity for AR when compared with BPH [149]. Remarkably, AR is a direct negatively regulated target of p53 [150, 151]. Due to persistent pregnancy of dairy cows, commercial milk contains increased amounts of androgen-precursors recently related to pathogenesis of $\mathrm{Av}$ [152]. Milk-derived androgens as well as milk-derived miRNAs suppressing p53 may both enhance AR-dependent signaling.

There is accumulating evidence derived from systematic meta-analyses that raised serum IGF-1 levels are associated with increased risk of PCa [153-157]. At present, epidemiologists focus on the role of milk-induced IGF-1 signaling in $\mathrm{PCa}$ and have demonstrated a relationship between milk consumption, increased serum IGF-1 levels and increased risk of PCa [130]. Unfortunately, these IGF1 centered studies did not consider the potential influence of milk-derived miRNAs that are highly bioactive components of whole milk.

Reduced expression of DNMT1 plays an important role in the induction of epithelial-mesenchymal transition

Table 2 p53-dependent signaling pathways of milk, acne, and prostate cancer

\begin{tabular}{lllll}
\hline Targets & Milk & Acne & PCa & References \\
\hline IGF-1/IGF1R & + & + & + & $109,123-130$ \\
FOXO1 & $?$ & - & - & $86-88,90-94$ \\
Androgen/AR & + & + & + & $108,145,146$ \\
mTORC1 & + & + & + & $1114-117$ \\
Survivin & $?$ & + & + & $107-109$ \\
TRAIL & $?$ & - & - & $83,84,100-103$ \\
IL-6 & + & + & + & $141,144-146$ \\
miRNA-125b & + & $?$ & + & $15,27,32,33,29,180$ \\
miRNA-25 & + & $?$ & + & $27,36,180$ \\
\hline
\end{tabular}

IGF-1 insulin-like growth factor 1, IGF1R IGF1 receptor, FOXO1 forkhead box 01, $A R$ androgen receptor, TRAIL tumor necrosis factor-associated apoptosis-inducing ligand, IL-6 interleukin 6
(EMT) and cancer stem cell (CSC) phenotype in PCa cells, which has been associated with tumorigenesis and metastasis [158]. Reduction of DNMT1 by 5-azacytidine (5Aza) promoted EMT induction as well as CSCs in vitro [158]. Thus, reduced DNMT1 expression via continued uptake of milk-derived DNMT1-tageting miRNA-148a may promote EMT and the CSC phenotype facilitating PCa progression [158]. The absence of miRNA-148a and related DNMT1 signaling may explain why miRNAdeficient milk protein powder did not affect prostate tumor progression in two mouse models of benign and neoplastic lesions [159], whereas commercial milk including bioactive miRNAs added to PCa cells in culture significantly promoted cell proliferation [131].

\section{Milk-miRNA-125b counteracts antiandrogen therapy of prostate cancer}

Most clinical PCa specimens overexpress miRNA-125b, which is regarded as an oncogene of PCa $[160,161]$. miRNA-125b directly targets three key pro-apoptotic genes: TP53, BBC3 (Puma), and BAK1. Increasing the abundance of miRNA-125b results in a dramatic decrease in the levels of these apoptosis effectors in $\mathrm{PCa}$ cells [162]. Remarkably, androgen stimulation of PCa cells via AR up-regulates the expression of miRNA-125b (Fig. 2), thus reduces the expression of these proapoptotic proteins $[160,161]$. Bak1 expression was detected in $77.5 \%$ of primary and untreated localized $\mathrm{PCa}$, but only in 33\% of hormone-refractory PCa [163]. Therefore, downregulation of BAK1 by miRNA-125b may contribute to disease progression and resistance to treatment in PCa $[160,161]$. miRNA-125b was found to have the ability of rendering LNCaP cells resistant to androgen withdrawal [161]. Milk consumption during antiandrogen therapy of $\mathrm{PCa}$ via transfer of milk-derived miRNA-125b may counteract antiandrogen-induced suppression of miRNA-125b thereby reducing the level of PCa cell apoptosis.

Upregulated p53 interacts with the pro-apoptotic mitochondrial membrane protein Bak, which causes oligomerization of Bak and release of cytochrome c from mitochondria. Evidence has been provided that Bak may serve as a mitochondrial receptor for p53 [164]. Notably, the p53-Bak complex coincides with the loss of interaction between Bak and the anti-apoptotic Bcl2family member Mcl1. Thus, p53 and Mcl1 have opposing effects on mitochondrial apoptosis by interacting with, and modulating the activity of the death effector Bak [165, 166].

Milk-miRNAs targeting p53 may thus attenuate the p53-TRAIL-mediated extrinsic pathway of apoptosis and the p53-Bak-regulated intrinsic pathway of apoptosis promoting pro-survival signaling (Fig. 2). Remarkably, IGF binding protein 1 (IGFBP1) has been reported to 
increase during cow milk consumption [167]. IGFBP1 via binding to BAK impairs the formation of the proapoptotic p53/Bak complex [168].

\section{Conclusions}

Milk, the postnatal nutrient and signaling system of mammals, promotes growth and lifelong metabolic and immunological programming [169-172]. Milk's miRNAs provide an "ancestral maternal language" that shapes the genome of the breastfed infant [1-7]. Presented translational evidence and mechanistic plausibility allow the prediction that milk-derived miRNAs attenuate the guardians of the genome, p53 and DNMT1, and their complex interacting regulatory network regulating gene expression and chromatin structure (Fig. 1). We have to keep in mind that under physiological conditions milkdependent miRNA-mediated nutrigenomic effects are restricted to the lactation period, which is terminated after weaning in all mammals. In modern humans, however, technical interventions such as pasteurization and refrigerated storage of milk miRNAs allows lifelong exposure to milk's archaic miRNA-orchestrated signaling machinery that persistently disturbs p53- and DNMT-dependent gene regulation of the milk recipient. Milk-derived miRNA-125b and androgen-stimulated miRNA-125b thus operate synergistically as a natural doping system.

Genetic and epigenetic selection of dairy cows intended to increase lactation performance and milk yield further enhances the expression of lactationpromoting miRNAs such as miRNA-148a $[50,59]$. These miRNAs via milk exosome transfer finally target p53 and DNMTs of the milk consumer. Enhanced dairy cow lactation performance is thus an unnoticed risk factor that further increases the miRNA burden for the human milk consumer [6]. Persistent and increased milk miRNAmediated down-regulation of p53 and DNMT1 most likely enhances the risk of diseases of civilization such as are Av and PCa [173, 174]. Strikingly, Av and PCa share common milk-dependent signal transduction pathways (Fig. 2). In this regard, it is a well-grounded recommendation for adolescents and adults to avoid the intake of pasteurized whole or skim milk, which delivers bioactive miRNAs that modify the human genome. Evidence in support of the bioavailability of miRNAs encapsulated in dietary exosomes [2-8] outweighs studies produced by scholars doubting that this phenomenon is real [175-177]. These studies have been disputed due to several technical or methodological pitfalls discussed elsewhere [8, 21, 178, 179]. Nevertheless, some important issues need more detailed future studies: 1) Direct evidence is still missing that shows the uptake of milk exosome-derived miRNAs in peripheral cells of the milk recipient. 2) It is not known with certainty that milk-derived miRNAs reach sufficient intracellular concentrations modifying gene regulation. 3) Although accumulating evidence underlines the uptake of milk exosomal miRNAs by intestinal cells and vascular epithelial cells [17-22], no direct evidence of selective milk miRNA uptake by other organs such as the sebaceous or prostate gland has yet been provided. However, it is of critical concern, that today's milk contains and transfers oncogenic miRNAs involved in the cancerogenesis of PCa such as miRNA-21, miRNA-25, and miRNA-125b [180]. It is thus advisable to inactivate exosomal milk-derived miRNAs either via ultraheat or microwave treatment, ultra-sonication, or fermentation $[6,20,46,60,68]$ in order to prevent an unperceived hazardous contamination of the human food chain with oncogenic biosimilar miRNAs of another mammalian species such as Bos taurus.

\section{Abbreviations \\ AMPK: AMP-activated kinase; Av: Acne vulgaris; BPH: Benign prostatic hyperplasia; CSC: Cancer stem cell; DNMT: DNA methyltransferase; DR: Death receptor; EMT: Epithelial-mesenchymal transition; FOXO1: Forkhead box O1; HDAC: Histone deacetylase; IGF-1: Insulin-like growth factor-1; IGF1R: IGF1 receptor; MEC: Mammary epithelial cells; MFG: Milk fat globule; miRNA: Micro ribonucleic acid; mTORC1: Mechanistic target of rapamycin complex 1; PCa: Prostate cancer; PI3K: Phosphoinositide-3 kinase; PTEN: Phosphatase and tensin homolog; SREBP1: Sterol regulatory element binding protein 1; TRAIL: Tumor necrosis factor-related apoptosis-inducing ligand; TSC2: Tuberin; UTR: Untranslated region}

\section{Acknowledgements}

The author thanks Bruno Steinkraus, Ph.D., Oxford University, UK, for helpful discussion of miRNA base pairing and computerized predictions of miRNA target sites. Furthermore, the author thanks Rowan Nicholls, student of Oxford University, UK, for language improvements of this manuscript.

\section{Funding}

There is no source of funding.

Availability of data and materials Not applicable.

Authors' contributions

BCM wrote the manuscript, searched and critically reviewed the literature.

Ethics approval and consent to participate

Not applicable.

\section{Consent for publication}

Not applicable.

\section{Competing interests}

The author declares that he has no competing interests.

\section{Publisher's Note}

Springer Nature remains neutral with regard to jurisdictional claims in published maps and institutional affiliations.

Received: 22 May 2017 Accepted: 8 August 2017

Published online: 15 August 2017

References

1. Melnik BC. Milk - a nutrient system of mammalian evolution promoting mTORC1-dependent translation. Int J Mol Sci. 2015;16:17048-87. 
2. Alsaweed M, Hartmann PE, Geddes DT, Kakulas F. MicroRNAs in breastmilk and the lactating breast: potential immunoprotectors and developmental regulators for the infant and the mother. Int J Environ Res Public Health. 2015;12:13981-4020.

3. Melnik BC, John SM, Carrera-Bastos P, Schmitz G. Milk: a postnatal imprinting system stabilizing FoxP3 expression and regulatory T cell differentiation. Clin Transl Allergy. 2016;6:18.

4. Floris I, Kraft JD, Altosaar I. Roles of microRNA across prenatal and postnatal periods. Int J Mol Sci. 2016;17:E1994.

5. Zempleni J, Aguilar-Lozano A, Sadri M, Sukreet S, Manca S, Wu D, et al. Biological activities of extracellular vesicles and their cargos from bovine and human milk in humans and implications for infants. J Nutr. 2017;147:3-10.

6. Melnik BC, Schmitz G. Milk's role as an epigenetic regulator in health and disease. Diseases. 2017;5:12.

7. Perge P, Nagy Z, Decmann Á, Igaz I, Igaz P. Potential relevance of microRNAs in inter-species epigenetic communication, and implications for disease pathogenesis. RNA Biol. 2017;14:391-401.

8. Zempleni J. Milk exosomes: beyond dietary microRNAs. Genes Nutr. 2017;12:12.

9. Lane DP. Cancer. p53, guardian of the genome. Nature. 1992;358:15-6.

10. Hoh J, Jin S, Parrado T, Edington J, Levine AJ, Ott J. The p53MH algorithm and its application in detecting p53-responsive genes. Proc Natl Acad Sci U S A. 2002;99:8467-72.

11. Fischer M. Census and evaluation of p53 target genes. Oncogene. 2017;36: 3943-56.

12. Liu J, Zhang C, Zhao Y, Feng Z. MicroRNA control of p53. J Cell Biochem. 2017;118:7-14

13. Golan-Gerstl R, Shiff YE, Lavi-Moshayoff V, Leshkowitz DSD, Reif S. Characterization and biological function of milk-derived miRNAs. Mol Nutr Food Res. 2017 Jun 23; doi:10.1002/mnfr.201700009. [Epub ahead of print]

14. Culotta E, Koshland DE Jr. p53 sweeps through cancer research. Science. 1993;262:1958-61.

15. Weber JA, Baxter DH, Zhang S, Huang DY, Huang KH, Lee MJ, et al. The microRNA spectrum in 12 body fluids. Clin Chem. 2010;56:1733-41.

16. Foster BP, Balassa T, Benen TD, Dominovic M, Elmadjian GK, Florova V, et al. Extracellular vesicles in blood, milk and body fluids of the female and male urogenital tract and with special regard to reproduction. Crit Rev Clin Lab Sci. 2016;53:379-95.

17. Wolf T, Baier SR, Zempleni J. The intestinal transport of bovine milk exosomes is mediated by endocytosis in human colon carcinoma Caco-2 cells and rat small intestinal IEC-6 cells. J Nutr. 2015;145:2201-6.

18. Benmoussa A, Lee CH, Laffont B, Savard P, Laugier J, Boilard E, et al, Commercial dairy cow milk microRNAs resist digestion under simulated gastrointestinal tract conditions. J Nutr. 2016;146:2206-15.

19. Chen T, Xie MY, Sun JJ, Ye RS, Cheng X, Sun RP, et al. Porcine milk-derived exosomes promote proliferation of intestinal epithelial cells. Sci Rep. 2016;6:33862.

20. Kusuma RJ, Manca S, Friemel T, Sukreet S, Nguyen C, Zempleni J. Human vascular endothelial cells transport foreign exosomes from cow's milk by endocytosis. Am J Physiol Cell Physiol. 2016;310:C800-7.

21. Melnik BC, Kakulas F, Geddes DT, Hartmann PE, John SM, Carrera-Bastos P, et al. Milk miRNAs: simple nutrients or systemic functional regulators? Nutr Metab (Lond). 2016;13:42.

22. Hock A, Miyake H, Li B, Lee C, Ermini L, Koike Y, et al. Breast milk-derived exosomes promote intestinal epithelial cell growth. J Pediatr Surg. 2017:52:755-9.

23. Yu S, Zhao Z, Sun L, Li P. Fermentation results in quantitative changes in milk-derived exosomes and different effects on cell growth and survival. J Agric Food Chem. 2017;65:1220-8.

24. Cui J, Zhou B, Ross SA, Zempleni J. Nutrition, microRNAs, and human health. Adv Nutr. 2017;8:105-12

25. Liao Y, Du X, Li J, Lönnerdal B. Human milk exosomes and their microRNAs survive digestion in vitro and are taken up by human intestinal cells. Mol Nutr Food Res. 2017; Jul 7; doi:10.1002/mnfr.201700082. [Epub ahead of print]

26. Rani P, Vashisht M, Golla N, Shandilya S, Onteru SK, Singh D. Milk miRNAs encapsulated in exosomes are stable to human digestion and permeable to intestinal barrier in vitro. J Funct Foods. 2017:34:431-9.

27. Baier SR, Nguyen C, Xie F, Wood JR, Zempleni J. MicroRNAs are absorbed in biologically meaningful amounts from nutritionally relevant doses of cow milk and affect gene expression in peripheral blood mononuclear cells, HEK-293 kidney cell cultures, and mouse livers. J Nutr. 2014;144:1495-500.

28. Manca S, Giraud D, Zempleni J. Bioavailability and biodistribution of fluorophore-labeled exosomes from cow's milk after intravenous and oral administration in C57BI/6J mice. FASEB J. 2016;30:690.8.
29. Manca S, Giraud D, Zempleni J. The bioavailability and distribution of bovine milk exosomes is distinct from that of their cargos in mice. FASEB J. 2017;31: 148.2 .

30. Munagala R, Aqil F, Jeyabalan J, Gupta RC. Bovine milk-derived exosomes for drug delivery. Cancer Lett. 2016;371:48-61.

31. Agrawal AK, Aqil F, Jeyabalan J, Spencer WA, Beck J, Gachuki BW, et al. Milkderived exosomes for oral delivery of paclitaxel. Nanomedicine. 2017;13:1627-36.

32. Le MT, Teh C, Shyh-Chang N, Xie H, Zhou B, Korzh V, et al. MicroRNA-125b is a novel negative regulator of p53. Genes Dev. 2009;23:862-76.

33. Le MT, Shyh-Chang N, Khaw SL, Chin L, Teh C, Tay J, et al. Conserved regulation of p53 network dosage by microRNA-125b occurs through evolving miRNA-target gene pairs. PLoS Genet. 2011;7:e1002242.

34. Zhou Q, Li M, Wang X, Li Q, Wang T, Zhu Q, et al. Immune-related microRNAs are abundant in breast milk exosomes. Int J Biol Sci. 2012;8:118-23.

35. Baddela VS, Nayan V, Rani P, Onteru SK, Singh D. Physicochemical biomolecular insights into buffalo milk-derived nanovesicles. Appl Biochem Biotechnol. 2016; 178:544-57.

36. Chen T, Xi QY, Ye RS, Cheng X, Qi QE, Wang SB, et al. Exploration of microRNAs in porcine milk exosomes. BMC Genomics. 2014;15:100.

37. Kumar M, Lu Z, Takwi AA, Chen W, Callander NS, Ramos KS, et al. Negative regulation of the tumor suppressor p53 gene by microRNAs. Oncogene. 2011;30:843-53.

38. Chen X, Gao C, Li H, Huang L, Sun Q, Dong Y, et al. Identification and characterization of microRNAs in raw milk during different periods of lactation, commercial fluid, and powdered milk products. Cell Res. 2010;20:1128-37.

39. Gu Y, Li M, Wang T, Liang Y, Zhong Z, Wang X, et al. Lactation-related microRNA expression profiles of porcine breast milk exosomes. PLoS One. 2012;7:e43691.

40. Alsaweed M, Lai CT, Hartmann PE, Geddes DT, Kakulas F. Human milk cells contain numerous miRNAs that may change with milk removal and regulate multiple physiological processes. Int J Mol Sci. 2016;17:E956.

41. Hoffman RM. Is DNA methylation the new guardian of the genome? Mol Cytogenet. 2017;10:11

42. Li E, Zhang Y. DNA methylation in mammals. Cold Spring Harb Perspect Biol. 2014;6:a019133.

43. Denis $\mathrm{H}$, Ndlovu MN, Fuks F. Regulation of mammalian DNA methyltransferases: a route to new mechanisms. EMBO Rep. 2011;12:647-56.

44. Bilian Jin B, Robertson KD. DNA methyltransferases (DNMTs), DNA damage repair, and cancer. Adv Exp Med Biol. 2013;754:3-29.

45. Chaudry SF, Chevassut TJ. Epigenetic guardian: a review of the DNA methyltransferase DNMT3A in acute myeloid leukaemia and clonal haematopoiesis. Biomed Res Int. 2017;2017:5473197.

46. Szyf M. The role of DNA methyltransferase 1 in growth control. Front Biosci. 2001;6:D599-609.

47. Fuks F, Burgers WA, Brehm A, Hughes-Davies L, Kouzarides T. DNA methyltransferase Dnmt1 associates with histone deacetylase activity. Nat Genet. 2000:24:88-91.

48. Robertson KD, Ait-Si-Ali S, Yokochi T, Wade PA, Jones PL, Wolffe AP. DNMT1 forms a complex with Rb, E2F1 and HDAC1 and represses transcription from E2F-responsive promoters. Nat Genet. 2000;25:338-42.

49. Izumi H, Kosaka N, Shimizu T, Sekine K, Ochiya T, Takase M. Bovine milk contains microRNA and messenger RNA that are stable under degradative conditions. J Dairy Sci. 2012:95:4831-41.

50. Kirchner B, Pfaffl MW, Dumpler J, von Mutius E, Ege MJ. microRNA in native and processed cow's milk and its implication for the farm milk effect on asthma. J Allergy Clin Immunol. 2016;137:1893-1895.e13.

51. Munch EM, Harris RA, Mohammad M, Benham AL, Pejerrey SM, Showalter L, et al. Transcriptome profiling of microRNA by next-gen deep sequencing reveals known and novel miRNA species in the lipid fraction of human breast milk. PLoS One. 2013;8:e50564.

52. Gallier S, Vocking K, Post JA, Van De Heijning B, Acton D, Van Der Beek EM, et al. A novel infant milk formula concept: mimicking the human milk fat globule structure. Colloids Surf B Biointerfaces. 2015;136:329-39.

53. Do DN, Li R, Dudemaine PL, Ibeagha-Awemu EM. MicroRNA roles in signalling during lactation: an insight from differential expression, time course and pathway analyses of deep sequence data. Sci Rep. 2017;7:44605.

54. Chen Y, Song YX, Wang ZN. The microRNA-148/152 family: multi-faceted players. Mol Cancer. 2013;12:43.

55. Wang J, Bian Y, Wang Z, Li D, Wang C, Li Q, et al. MicroRNA-152 regulates DNA methyltransferase 1 and is involved in the development and lactation of mammary glands in dairy cows. PLoS One. 2014;9:e101358. 
56. Pan W, Zhu S, Yuan M, Cui H, Wang L, Luo X, et al. MicroRNA-21 and microRNA148a contribute to DNA hypomethylation in lupus CD4+ T cells by directly and indirectly targeting DNA methyltransferase 1. J Immunol. 2010;184:6773-81.

57. Long XR, He Y, Huang C, Li J. MicroRNA-148a is silenced by hypermethylation and interacts with DNA methyltransferase 1 in hepatocellular carcinogenesis. Int J Oncol. 2014:44:1915-22.

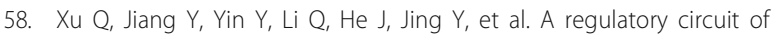
miR-148a/152 and DNMT1 in modulating cell transformation and tumor angiogenesis through IGF-IR and IRS1. J Mol Cell Biol. 2013;5:3-13.

59. Muroya S, Hagi T, Kimura A, Aso H, Matsuzaki M, Nomura M. Lactogenic hormones alter cellular and extracellular microRNA expression in bovine mammary epithelial cell culture. J Anim Sci Biotechnol. 2016;7:8.

60. Chen Z, Luo J, Sun S, Cao D, Shi H, Loor JJ. miR-148a and miR-17-5p synergistically regulate milk TAG synthesis via PPARGC1A and PPARA in goat mammary epithelial cells. RNA Biol. 2017;14:326-38.

61. Braud M, Magee DA, Park SD, Sonstegard TS, Waters SM, MacHugh DE, et al. Genome-wide microRNA binding site variation between extinct wild aurochs and modern cattle identifies candidate microRNA-regulated domestication genes. Front Genet. 2017;8:3.

62. Do DN, Dudemaine PL, Li R, Ibeagha-Awemu EM. Co-expression network and pathway analyses reveal important modules of miRNAs regulating milk yield and component traits. Int J Mol Sci. 2017;18(7):E1560. doi:10.3390/ ijms18071560.

63. Estève PO, Chin HG, Pradhan S. Human maintenance DNA (cytosine-5)methyltransferase and p53 modulate expression of p53-repressed promoters. Proc Natl Acad Sci U S A. 2005;102:1000-5.

64. Espada J, Ballestar E, Fraga MF, Villar-Garea A, Juarranz A, Stockert JC, et al. Human DNA methyltransferase 1 is required for maintenance of the histone H3 modification pattern. J Biol Chem. 2004;279:37175-84.

65. Eslami M, Khamechian T, Mazoochi T, Ehteram H, Sehat M, Alizargar J. Evaluation of survivin expression in prostate specimens of patients with prostate adenocarcinoma and benign prostate hyperplasia underwent transurethral resection of the prostate or prostatectomy. Spring. 2016;5:621.

66. Hoffman WH, Biade S, Zilfou JT, Chen J, Murphy M. Transcriptional repression of the anti-apoptotic survivin gene by wild type p53. J Biol Chem. 2002;277: 3247-57.

67. Howard KM, Jati Kusuma R, Baier SR, Friemel T, Markham L, Vanamala J, et al. Loss of miRNAs during processing and storage of cow's (Bos Taurus) milk. J Agric Food Chem. 2015;63:588-92.

68. Sluijs I, Forouhi NG, Beulens JW, van der Schouw YT, Agnoli C, Arriola L, et al. The amount and type of dairy product intake and incident type 2 diabetes: results from the EPIC-InterAct study. Am J Clin Nutr. 2012;96:382-90.

69. Adebamowo CA, Spiegelman D, Danby FW, Frazier AL, Willett WC, Holmes MD. High school dietary dairy intake and teenage acne. J Am Acad Dermatol. 2005:52:207-14.

70. Adebamowo CA, Spiegelman D, Berkey CS, Danby FW, Rockett HH, Colditz $G A$, et al. Milk consumption and acne in adolescent girls. Dermatol Online J. 2006;12:1

71. Adebamowo CA, Spiegelman D, Berkey CS, Danby FW, Rockett HH, Colditz GA, et al. Milk consumption and acne in teenaged boys. J Am Acad Dermatol. 2008:58:787-93.

72. Melnik BC. Evidence for acne-promoting effects of milk and other insulinotropic dairy products. Nestle Nutr Workshop Ser Pediatr Program. 2011;67:131-45.

73. Di Landro A, Cazzaniga S, Parazzini F, Ingordo V, Cusano F, Atzori L, et al. Family history, body mass index, selected dietary factors, menstrual history, and risk of moderate to severe acne in adolescents and young adults. J Am Acad Dermatol. 2012;67:1129-35

74. Ismail NH, Manaf ZA, Azizan NZ. High glycemic load diet, milk and ice cream consumption are related to acne vulgaris in Malaysian young adults: a case control study. BMC Dermatol. 2012;12:13.

75. Burris J, Rietkerk W, Woolf K. Relationships of self-reported dietary factors and perceived acne severity in a cohort of New York young adults. J Acad Nutr Diet. 2014;114:384-92.

76. Melnik BC. Linking diet to acne metabolomics, inflammation, and comedogenesis: an update. Clin Cosmet Investig Dermatol. 2015;8:371-88.

77. LaRosa CL, Quach KA, Koons K, Kunselman AR, Zhu J, Thiboutot DM, et al. Consumption of dairy in teenagers with and without acne. J Am Acad Dermatol. 2016;75:318-22.

78. Grossi E, Cazzaniga S, Crotti S, Naldi L, Di Landro A, Ingordo V, et al. The constellation of dietary factors in adolescent acne: a semantic connectivity map approach. J Eur Acad Dermatol Venereol. 2016;30:96-100.
79. Fiedler F, Stangl Gl, Fiedler E, Taube KM. Acne and nutrition: a systematic review. Acta Derm Venereol. 2017;97:7-9.

80. Ulvestad M, Bjertness E, Dalgard F, Halvorsen JA. Acne and dairy products in adolescence: results from a Norwegian longitudinal study. J Eur Acad Dermatol Venereol. 2017;31:530-5.

81. Melnik BC. Pro-inflammatory sebocyte growth and survival signalling in acne vulgaris are reversed by pro-apoptotic isotretinoin signalling. Exp Dermatol. 2016;25:676-7.

82. Melnik BC. The TRAIL to acne pathogenesis: let's focus on death pathways. Exp Dermatol. 2017;26:270-2

83. Nelson AM, Cong Z, Gilliland KL, Thiboutot DM. TRAlL contributes to the apoptotic effect of 13-cis retinoic acid in human sebaceous gland cells. Br J Dermatol. 2011;165:526-33.

84. Melnik BC. Apoptosis may explain the pharmacological mode of action and adverse effects of isotretinoin, including teratogenicity. Acta Derm Venereol. 2017;97:173-81.

85. Lee DD, Stojadinovic O, Krzyzanowska A, Vouthounis C, Blumenberg M, Tomic-Canic M. Retinoid-responsive transcriptional changes in epidermal keratinocytes. J Cell Physiol. 2009:220:427-39.

86. Melnik BC. FoxO1 - the key for the pathogenesis and therapy of acne? J Dtsch Dermatol Ges. 2010;8:105-14

87. Mirdamadi Y, Thielitz A, Wiede A, Goihl A, Papakonstantinou E, Hartig R, et al. Insulin and insulin-like growth factor-1 can modulate the phosphoinositide-3-kinase/Akt/FoxO1 pathway in SZ95 sebocytes in vitro. Mol Cell Endocrinol. 2015;415:32-44.

88. Agamia NF, Abdallah DM, Sorour O, Mourad B, Younan DN. Skin expression of mammalian target of rapamycin and forkhead box transcription factor 01 , and serum insulin-like growth factor-1 in patients with acne vulgaris and their relationship with diet. Br J Dermatol. 2016;174:1299-307.

89. Gross DN, van den Heuvel AP, Birnbaum MJ. The role of FoxO in the regulation of metabolism. Oncogene. 2008;27:2320-36.

90. Fan W, Yanase T, Morinaga H, Okabe T, Nomura M, Daitoku H, et al. Insulinlike growth factor 1 /insulin signaling activates androgen signaling through direct interactions of Foxo1 with androgen receptor. J Biol Chem. 2007;282: 7329-38.

91. Ma Q, Fu W, Li P, Nicosia SV, Jenster G, Zhang X, et al. FoxO1 mediates PTEN suppression of androgen receptor $\mathrm{N}$ - and C-terminal interactions and coactivator recruitment. Mol Endocrinol. 2009;23:213-25.

92. Yanase T, Fan W. Modification of androgen receptor function by IGF-1 signaling implications in the mechanism of refractory prostate carcinoma. Vitam Horm. 2009;80:649-66.

93. Bohrer LR, Liu P, Zhong J, Pan Y, Angstman J, Brand L, et al. FOXO1 binds to the TAU5 motif and inhibits constitutively active androgen receptor splice variants. Prostate. 2013;73:1017-27.

94. Zhao Y, Tindall DJ, Huang H. Modulation of androgen receptor by FOXA1 and FOXO1 factors in prostate cancer. Int J Biol Sci. 2014;10:614-9.

95. Deng X, Zhang W, O-Sullivan I, Williams JB, Dong Q, Park EA, et al. FoxO1 inhibits sterol regulatory element-binding protein-1c (SREBP-1C) gene expression via transcription factors Sp1 and SREBP-1c. J Biol Chem. 2012; 287:20132-43.

96. Zhang Y, Zhang L, Sun H, Lv Q, Qiu C, Che X, et al. Forkhead transcription factor 1 inhibits endometrial cancer cell proliferation via sterol regulatory element-binding protein 1. Oncol Lett. 2017;13:731-7.

97. Smith TM, Gilliland K, Clawson GA, Thiboutot D. IGF-1 induces SREBP-1 expression and lipogenesis in SEB-1 sebocytes via activation of the phosphoinositide 3kinase/Akt pathway. J Invest Dermatol. 2008;128:1286-93.

98. Pappas K, Xu J, Zairis S, Resnick-Silverman L, Abate F, Steinbach N, et al. p53 maintains baseline expression of multiple tumor suppressor genes. Mol Cancer Res. 2017 May 8; doi:10.1158/1541-7786.MCR-17-0089. [Epub ahead of print]

99. Assmann G, Wagner AD, Monika M, Pfoehler C, Pfreundschuh M, Tilgen W, et al. Single-nucleotide polymorphisms p53 G72C and Mdm2 T309G in patients with psoriasis, psoriatic arthritis, and SAPHO syndrome. Rheumatol Int. 2010;30:1273-6.

100. Voelkel-Johnson C. TRAIL-mediated signaling in prostate, bladder and renal cancer. Nat Rev Urol. 2011;8:417-27.

101. Faroogi AA, De Rosa G. TRAIL and microRNAs in the treatment of prostate cancer: therapeutic potential and role of nanotechnology. Appl Microbiol Biotechnol. 2013:97:8849-57.

102. Farooqi AA, Qureshi MZ, Rehman A, Nogueira DR, Awan II, Shahid A. Prostate cancer: leading and misleading routes to TRAIL of death. Pak J Pharm Sci. 2014;27:1371-7. 
103. Das D, Persaud L, Dejoie J, Happy M, Brannigan O, De Jesus D, et al. Tumor necrosis factor-related apoptosis-inducing ligand (TRAIL) activates caspases in human prostate cancer cells through sigma 1 receptor. Biochem Biophys Res Commun. 2016;470:319-23.

104. Kuribayashi K, Krigsfeld G, Wang W, Xu J, Mayes PA, Dicker DT, et al. TNFSF10 (TRAIL), a p53 target gene that mediates p53-dependent cell death. Cancer Biol Ther. 2008;7:2034-8.

105. Torfadottir JE, Steingrimsdottir L, Mucci L, Aspelund T, Kasperzyk JL, Olafsson $\mathrm{O}$, et al. Milk intake in early life and risk of advanced prostate cancer. Am J Epidemiol. 2012;175:144-53.

106. Sutcliffe $S$, Giovannucci E, Isaacs WB, Willett WC, Platz EA. Acne and risk of prostate cancer. Int J Cancer. 2007;121:2688-92.

107. Kim H, Moon SY, Sohn MY, Lee WJ. Insulin-like growth factor-1 increases the expression of inflammatory biomarkers and sebum production in cultured sebocytes. Ann Dermatol. 2017;29:20-5.

108. Lai JJ, Chang P, Lai KP, Chen L, Chang C. The role of androgen and androgen receptor in skin-related disorders. Arch Dermatol Res. 2012;304:499-510.

109. Assaf HA, Abdel-Maged WM, Elsadek BE, Hassan MH, Adly MA, Ali SA. Survivin as a novel biomarker in the pathogenesis of acne vulgaris and its correlation to insulin-like growth factor-I. Dis Markers. 2016;2016:7040312.

110. Downer MK, Batista JL, Mucci LA, Stampfer MJ, Epstein MM, Håkansson N, et al. Dairy intake in relation to prostate cancer survival. Int J Cancer. 2017; 140:2060-9.

111. Pettersson A, Kasperzyk JL, Kenfield SA, Richman EL, Chan JM, Willett WC, et al. Milk and dairy consumption among men with prostate cancer and risk of metastases and prostate cancer death. Cancer Epidemiol Biomark Prev. 2012;21:428-36.

112. Song Y, Chavarro JE, Cao Y, Qiu W, Mucci L, Sesso HD, et al. Whole milk intake is associated with prostate cancer-specific mortality among U.S. male physicians. J Nutr. 2013;143:189-96.

113. Lu W, Chen H, Niu Y, Wu H, Xia D, Wu Y. Dairy products intake and cancer mortality risk: a meta-analysis of 11 population-based cohort studies. Nutr J. 2016;15:91.

114. Melnik BC. Western diet-induced imbalances of FoxO1 and mTORC1 signalling promote the sebofollicular inflammasomopathy acne vulgaris. Exp Dermatol. 2016;25:103-4.

115. Monfrecola G, Lembo S, Caiazzo G, De Vita V, Di Caprio R, Balato A, et al Mechanistic target of rapamycin (mTOR) expression is increased in acne patients' skin. Exp Dermatol. 2016:25:153-5.

116. Hsieh AC, Liu Y, Edlind MP, Ingolia NT, Janes MR, Sher A, et al. The translational landscape of mTOR signalling steers cancer initiation and metastasis. Nature. 2012;485:55-61.

117. Melnik BC, John SM, Carrera-Bastos P, Cordain L. The impact of cow's milkmediated mTORC1-signaling in the initiation and progression of prostate cancer. Nutr Metab (Lond). 2012;9:74.

118. Foster KG, Fingar DC. Mammalian target of rapamycin (mTOR): conducting the cellular signaling symphony. J Biol Chem. 2010;285:14071-7.

119. Hung CM, Garcia-Haro L, Sparks CA, Guertin DA. mTOR-dependent cell survival mechanisms. Cold Spring Harb Perspect Biol. 2012;4:a008771.

120. Melnik BC, John SM, Schmitz G. Milk is not just food but most likely a genetic transfection system activating mTORC1 signaling for postnatal growth. Nutr J. 2013;12:103.

121. Cargnello M, Tcherkezian J, Roux PP. The expanding role of mTOR in cancer cell growth and proliferation. Mutagenesis. 2015;30:169-76.

122. Ben-Sahra I, Manning BD. mTORC1 signaling and the metabolic control of cell growth. Curr Opin Cell Biol. 2017;45:72-82

123. Hoppe C, Mølgaard C, Juul A, Michaelsen KF. High intakes of skimmed milk, but not meat, increase serum IGF-I and IGFBP-3 in eight-year-old boys. Eur J Clin Nutr. 2004;58:1211-6.

124. Rich-Edwards JW, Ganmaa D, Pollak MN, Nakamoto EK, Kleinman K, Uush Tserendolgor $\mathrm{U}$, et al. Milk consumption and the prepubertal somatotropic axis. Nutr J. 2007;6:28.

125. Qin LQ, He K, Xu JY. Milk consumption and circulating insulin-like growth factor-I level: a systematic literature review. Int J Food Sci Nutr. 2009; 60(Suppl 7):330-40.

126. Cappel M, Mauger D, Thiboutot D. Correlation between serum levels of insulin-like growth factor 1, dehydroepiandrosterone sulfate, and dihydrotestosterone and acne lesion counts in adult women. Arch Dermatol. 2005;141:333-8.

127. Vora S, Ovhal A, Jerajani H, Nair N, Chakrabortty A. Correlation of facial sebum to serum insulin-like growth factor-1 in patients with acne. $\mathrm{Br} \mathrm{J}$ Dermatol. 2008;159:990-1.
128. Melnik BC, Schmitz G. Role of insulin, insulin-like growth factor-1, hyperglycaemic food and milk consumption in the pathogenesis of acne vulgaris. Exp Dermatol. 2009;18:833-41.

129. Melnik BC, John SM, Schmitz G. Over-stimulation of insulin/IGF-1 signaling by western diet may promote diseases of civilization: lessons learnt from Laron syndrome. Nutr Metab (Lond). 2011;8:41.

130. Harrison S, Lennon R, Holly J, Higgins JPT, Gardner M, Perks C, et al. Does milk intake promote prostate cancer initiation or progression via effects on insulin-like growth factors (IGFs)? A systematic review and meta-analysis. Cancer Causes Control. 2017;28:497-528.

131. Tate PL, Bibb R, Larcom LL. Milk stimulates growth of prostate cancer cells in culture. Nutr Cancer. 2011;63:1361-6.

132. Lee JH, Budanov AV, Park EJ, Birse R, Kim TE, Perkins GA, et al. Sestrin as a feedback inhibitor of TOR that prevents age-related pathologies. Science. 2010;327:1223-8.

133. Budanov AV. Stress-responsive sestrins link p53 with redox regulation and mammalian target of rapamycin signaling. Antioxid Redox Signal. 2011;15: 1679-90.

134. Werner H, Karnieli E, Rauscher FJ, LeRoith D. Wild-type and mutant p53 differentially regulate transcription of the insulin-like growth factor I receptor gene. Proc Natl Acad Sci U S A. 1996;93:8318-23.

135. Werner H, Sarfstein R, LeRoith D, Bruchim I. Insulin-like growth factor 1 signaling axis meets p53 genome protection pathways. Front Oncol. 2016;6:159.

136. Bénard J, Douc-Rasy S, Ahomadegbe JC. TP53 family members and human cancers. Hum Mutat. 2003;21:182-91.

137. Lee JT, Lehmann BD, Terrian DM, Chappell WH, Stivala F, Libra M, et al. Targeting prostate cancer based on signal transduction and cell cycle pathways. Cell Cycle. 2008;7:1745-62.

138. Tomkova K, Tomka M, Zajac V. Contribution of p53, p63, and p73 to the developmental diseases and cancer. Neoplasma. 2008:55:177-81.

139. Dean JL, Knudsen KE. The role of tumor suppressor dysregulation in prostate cancer progression. Curr Drug Targets. 2013;14:460-71.

140. Munda M, Hajdinjak T, Kavalar R, Stiblar MD. p53, Bcl-2 and AgNOR tissue markers: model approach in predicting prostate cancer characteristics. J Int Med Res. 2009;37:1868-76

141. Spyridonidis T, Giannakenas C, Papandrianos N, Barla P, Apostolopoulos DJ. Two cases of synovitis, acne, pustulosis, osteitis-SAPHO syndrome. Hell J Nucl Med. 2007:10:109-12.

142. Michaëlsson K, Wolk A, Langenskiöld S, Basu S, Warensjö Lemming E, Melhus $\mathrm{H}$, et al. Milk intake and risk of mortality and fractures in women and men: cohort studies. BMJ. 2014;349:96015.

143. Zhang T, Li H, Shi J, Li S, Li M, Zhang L, et al. p53 predominantly regulates IL-6 production and suppresses synovial inflammation in fibroblast-like synoviocytes and adjuvant-induced arthritis. Arthritis Res Ther. 2016;18:271.

144. Liu D, Xu Y. p53, oxidative stress, and aging. Antioxid Redox Signal. 2011;15: 1669-78.

145. Culig Z. Proinflammatory cytokine interleukin-6 in prostate carcinogenesis. Am J Clin Exp Urol. 2014;2:231-8

146. Alestas T, Ganceviciene R, Fimmel S, Müller-Decker K, Zouboulis CC. Enzymes involved in the biosynthesis of leukotriene B4 and prostaglandin E2 are active in sebaceous glands. J Mol Med (Berl). 2006:84:75-87.

147. Kelhälä HL, Palatsi R, Fyhrquist N, Lehtimäki S, Väyrynen JP, Kallioinen M, et al. IL-17/Th17 pathway is activated in acne lesions. PLoS One. 2014:9:e105238.

148. Chatterjee B. The role of the androgen receptor in the development of prostatic hyperplasia and prostate cancer. Mol Cell Biochem. 2003;253:89-101.

149. Husain I, Shukla S, Soni P, Husain N. Role of androgen receptor in prostatic neoplasia versus hyperplasia. J Cancer Res Ther. 2016;12:112-6.

150. Shenk JL, Fisher CJ, Chen SY, Zhou XF, Tillman K, Shemshedini L. p53 represses androgen-induced transactivation of prostate-specific antigen by disrupting hAR amino- to carboxyl-terminal interaction. J Biol Chem. 2001; 276:38472-9.

151. Alimirah F, Panchanathan R, Chen J, Zhang X, Ho SM, Choubey D. Expression of androgen receptor is negatively regulated by $\mathrm{p} 53$. Neoplasia. 2007:9:1152-9.

152. Danby FW. Acne, dairy and cancer: the 5alpha-P link. Dermatoendocrinol. 2009;1:12-6.

153. Giovannucci E. Insulin-like growth factor-l and binding protein-3 and risk of cancer. Horm Res. 1999:51(Suppl 3):34-41.

154. Renehan AG, Zwahlen M, Minder C, O'Dwyer ST, Shalet SM, Egger M. Insulin-like growth factor (IGF)-I, IGF binding protein-3, and cancer risk: systematic review and meta-regression analysis. Lancet. 2004;363:1346-53. 
155. Rowlands MA, Gunnell D, Harris R, Vatten LJ, Holly JM, Martin RM. Circulating insulin-like growth factor peptides and prostate cancer risk: a systematic review and meta-analysis. Int J Cancer. 2009;124:2416-29.

156. Rowlands MA, Holly JM, Hamdy F, Phillips J, Goodwin L, Marsden G, et al. Serum insulin-like growth factors and mortality in localised and advanced clinically detected prostate cancer. Cancer Causes Control. 2012;23:347-54.

157. Shanmugalingam T, Bosco C, Ridley AJ, Van Hemelrijck M. Is there a role for IGF-1 in the development of second primary cancers? Cancer Med. 2016;5: 3353-67.

158. Lee E, Wang J, Yumoto K, Jung Y, Cackowski FC, Decker AM, et al. DNMT1 regulates epithelial-mesenchymal transition and cancer stem cells, which promotes prostate cancer metastasis. Neoplasia. 2016;18:553-66.

159. Bernichtein S, Pigat N, Capiod T, Boutillon F, Verkarre V, Camparo P, et al. High milk consumption does not affect prostate tumor progression in two mouse models of benign and neoplastic lesions. PLoS One. 2015:10: e0125423.

160. Shi XB, Xue L, Yang J, Ma AH, Zhao J, Xu M, et al. An androgen-regulated miRNA suppresses Bak1 expression and induces androgen-independent growth of prostate cancer cells. Proc Natl Acad Sci U S A. 2007;104:19983-8.

161. DeVere White RW, Vinall RL, Tepper CG, Shi XB. MicroRNAs and their potential for translation in prostate cancer. Urol Oncol. 2009;27:307-11.

162. Shi XB, Xue L, Ma AH, Tepper CG, Kung HJ, White RW. miR-125b promotes growth of prostate cancer xenograft tumor through targeting pro-apoptotic genes. Prostate. 2011;71:538-49.

163. Yoshino T, Shiina H, Urakami S, Kikuno N, Yoneda T, Shigeno K, et al. Bcl-2 expression as a predictive marker of hormone-refractory prostate cancer treated with taxane-based chemotherapy. Clin Cancer Res. 2006;12:6116-24.

164. Pietsch EC, Leu JI, Frank A, Dumont P, George DL, Murphy ME. The tetramerization domain of p53 is required for efficient BAK oligomerization. Cancer Biol Ther. 2007;6:1576-83.

165. Leu JI, Dumont P, Hafey M, Murphy ME, George DL. Mitochondrial p53 activates Bak and causes disruption of a Bak-Mcl1 complex. Nat Cell Biol. 2004:6:443-50

166. Murphy ME, Leu Jl, George DL. p53 moves to mitochondria: a turn on the path to apoptosis. Cell Cycle. 2004;3:836-9.

167. Agostoni C, Turck D. Is cow's milk harmful to a child's health? J Pediatr Gastroenterol Nutr. 2011:53:594-600.

168. Leu Jl, George DL. Hepatic IGFBP1 is a prosurvival factor that binds to BAK, protects the liver from apoptosis, and antagonizes the proapoptotic actions of p53 at mitochondria. Genes Dev. 2007;21:3095-109.

169. Landecker $H$. Food as exposure: nutritional epigenetics and the new metabolism. BioSocieties. 2011;6:167-94.

170. Vickers MH. Early life nutrition, epigenetics and programming of later life disease. Nutrients. 2014;6:2165-78.

171. Zheng J, Xiao X, Zhang Q, Yu M. DNA methylation: the pivotal interaction between early-life nutrition and glucose metabolism in later life. $\mathrm{Br} J$ Nutr. 2014;112:1850-7.

172. Godfrey KM, Costello PM, Lillycrop KA. Development, epigenetics and metabolic programming. Nestle Nutr Inst Workshop Ser. 2016;85:71-80.

173. Cordain L, Lindeberg S, Hurtado M, Hill K, Eaton SB, Brand-Miller J. Acne vulgaris: a disease of western civilization. Arch Dermatol. 2002;138:1584-90.

174. Global Burden of Disease Cancer Collaboration, Fitzmaurice C, Allen C, Barber RM, Barregard L, Bhutta ZA, Brenner H, et al. Global, regional, and national cancer incidence, mortality, years of life lost, years lived with disability, and disability-adjusted life-years for 32 cancer groups, 1990 to 2015: A systematic analysis for the Global Burden of Disease Study. JAMA Oncol. 2017;3:524-48.

175. Witwer KW. Diet-responsive mammalian miRNAs are likely endogenous. J Nutr. 2014;144:1880-1.

176. Title AC, Denzler R, Stoffel M. Uptake and function studies of maternal milkderived microRNAs. J Biol Chem. 2015:290:23680-91.

177. Auerbach A, Vyas G, Li A, Halushka M, Witwer K. Uptake of dietary milk miRNAs by adult humans: a validation study. F1000Res. 2016;5:721.

178. Baier SR, Xie F, Zempleni J. Reply to Witwer. J Nutr. 2014;144:1882.

179. Zempleni J, Baier SR, Hirschi K. Diet-responsive microRNAs are likely exogenous. J Biol Chem. 2015:290:25197.

180. Vanacore D, Boccellino M, Rossetti S, Cavaliere C, D'Aniello C, Di Franco R, et al. Micrornas in prostate cancer: an overview. Oncotarget. 2017; doi:10.18632/ oncotarget.16933. [Epub ahead of print]

\section{Submit your next manuscript to BioMed Central and we will help you at every step:}

- We accept pre-submission inquiries

- Our selector tool helps you to find the most relevant journal

- We provide round the clock customer support

- Convenient online submission

- Thorough peer review

- Inclusion in PubMed and all major indexing services

- Maximum visibility for your research

Submit your manuscript at www.biomedcentral.com/submit
) Biomed Central 